GLOBAL JOURNAL OF SOCIAL SCIENCES VOL 19, 2020: 35-47

COPYRIGHT@ BACHUDO SCIENCE CO. LTD PRINTED IN NIGERIA. ISSN 1596-6216

35

www.globaljournalseries.com; Info@globaljournalseries.com

\title{
GOVERNMENT PROJECT FAILURE IN DEVELOPING COUNTRIES: A REVIEW WITH PARTICULAR REFERENCE TO NIGERIA
}

\section{KING MATTHEW EJA AND MANU RAMEGOWDA}

(Received 10 September 2019, Revision Accepted 26 September 2019)

\begin{abstract}
Governments and organizations, especially governments in developing countries, have witnessed project failures in their project implementation, although there might be some differences in the causes, effects and consequences of such failures among governments. This study aimed at investigating the causes, effects and consequences of project failures in developing countries with particular reference to Nigeria, through literature review. Information on project failures in Africa, Asia and little in Europe were sourced through journals, books and newspapers. It was apparent that project failure is very frequent in developing countries and in particular, Nigeria, with several causes, effects and consequences. Some of the causes established were poor financial capacity; inaccurate costing and corruption; incompetence and lack of knowledge; poor planning and estimation; poor communication; poor contracting and contractor practices; frequent design scope changes and errors; socio-cultural and political interference; poor leadership and corruption. The effects of project failure were found to be loss of revenue to the state; project cost overruns; loss of revenue by citizens; substandard infrastructure and low empowerment to community. The resultant consequences were slow economic growth; sector-centric underdevelopment; loss of foreign aid/grants; tougher donor regulations; loss of elections to incumbent leadership and lack of confidence in state from financial institutions. It is recommended that Nigerian government should overhaul its policy architecture to mitigating the causes of project failure, and in particular, stemming down corruption.
\end{abstract}

KEYWORDS: Government projects, project failure, poor implementation, corrupt practices, inadequate planning

\section{INTRODUCTION}

Government projects of any nation are of immense importance to the citizens and residents of that nation as it forms part of the building blocks that support national growth. The successful execution of projects serves as a visible indicator of development in a country (Hanachor, 2013). Despite this, in developing countries such as Nigeria, majority of projects embarked on by the government are classified as failed projects (Hanachor, 2013).

King Matthew Eja, School of Science and Engineering Teesside University Middlesbrough, UK Manu Ramegowda, School of Science and Engineering Teesside University Middlesbrough, UK
According to PMI (Project Management Institute PMBOK) guide (2013), a project is a temporary endeavour which is aimed at creating a unique result. Note (2015) however, defines a project as a series of unique and related activities with a goal that must be achieved at a set time, within its cost constraints and in accordance with set specifications. There is no clear cut definition for project failure, and there seems to be differences in its acceptable definition. Amachree (1988) defines project failure as the incapability of a 
project to be completed within its set time, cost and quality specifications. Nzekwe et al. (2015) however suggest that regardless of a project's completion time and cost, it can still be considered as failed if the project does not fulfil its required purpose. In addition, many studies agree that cost overruns, time overruns and substandard quality are the primary causes of project failure (Turner, 1993; Atkinson, 1999; Belout and Gauvrean, 2004). Other causes include: poor planning, variation of project design and scope, inflation, contractor competence, inadequate cost estimation, just to mention a few (Cousillas et al., 2010; Nzekweet al., 2015).

The causes of project failure are numerous both in developed and developing nations, and studies have indicated that large amounts of funds have been lost by governments as a result of failed projects (Fabian and Amir, 2011; Damoah, 2015). These factors which lead to project failure consequently lead to stagnant growth in national development (Nweze, 2016). In order to curb these menace, various authors have recommended more investigation into the causes and effects of projects failure especially in developing countries (Damoah, 2015; Taherdoost and Keshavarzsalehc, 2016).

Globally, of course, project failure has resulted in the loss of large amounts of funds. Information system projects in the UK, power generation projects in Africa and construction projects in Asia are few examples that have experienced failure (Heeks, 2006; Fabian and Amir, 2011; Okereke, 2017; Shahhossein et al., 2018). An example is the Home Office where $£ 750$ million e-boarder scheme whose contract was awarded in 2007 and terminated as a failed project in 2010 (Alami, 2016).

The rate of project failure in developing countries has been found to be higher than the rate in developed countries (Ogwueleka, 2011; Damoah, 2015) thereby creating the need to embark on more development projects. These projects however, experience several challenges such as inefficient planning (Akande et al., 2018a), cost variation (Aziz, 2013), difficult stakeholders (Rajablu et al., 2015). Currently in Nigeria, the rate of project failure is alarming and these failed projects have high financial implications (Akande et al., 2018b) which consequently reduce the rate of development.

Different causes of project failure have been identified. For example, Soliman (2010) identified 29 causes of failure as a result of delays in Kuwait's construction projects. He went ahead to state that the major causes of these delays are design and finance-related problems. Damoah (2015) looked at delays in Zambia's road construction projects and identified the causes of these delays as poor supervision, contract modification, construction mistakes, inadequate or unavailable equipment, poor procurement practices, difficult financial processes, etc.

At present, the menace of project failure has prompted researchers to look into the underlying factors leading to these failures. A rather generic approach has been taken by some researchers (Liu et al., 2011; Aziz, 2013; Taherdoost and Keshavarzsalele, 2016) or have researched on project failure with regard to specific projects in certain industries (Oloruntobi, 2013; Patanakul, 2014; Kog, 2017).

Despite the numerous causes and effects of project failure known, studies on these causes and effects and consequences of project failure on the development of developing countries, are going on. The aim of this study was to review the causes, effects and consequences of project failure in developing countries, especially Nigeria.

\section{Overview of Project and Project Failure}

The delivery of successful projects involves the use of tools and methods to achieve its objectives during the execution phase (PMI, 2013), therefore, projects must be executed using a systematic and organised process in order to achieve success. In spite of the fact that the goal of every project is to be a success, Allen et al. (2014) suggest that project failure has attracted more attention. The impact of project failure when taken into account is regarded to be harmful. When referring to failure, it is not only in terms of abandonment, other aspects such as the goals of the project are considered. Various studies consider failure to have occurred when a project does not achieve its goals (Hoang and Rothaermel, 2005; Mirza, Pourzolfaghar and Shahnazari, 2013).

In recent years, governments and organisations have experienced project failure globally (Nelson, 2007; Abbasi, 2014; Patanakul, 2014; Damoah and Kumi, 2018). This failures directly translates to the loss of huge amounts of money by the government. For example, Solon (2015) reported in the mirror that the UK has wasted over $£ 100$ million on cancelled or failed IT projects from 2013-2014. Additionally, Innotas, which is a portfolio management provider conducted a research from January to March 2015, in which 126 IT project professionals were polled, and the results indicated that 55 percent of respondents 
had experienced project failure (Florentine, 2017). As a matter of fact, the cases of IS/IT project failure are numerous and this has spurred researchers and practitioners to examine the reasons responsible for these failures (Patanakul, 2014). In the construction industry, the issue of cost overruns have become more common both in developed and developing countries (Cheng, 2014). For Instance, the government of Egypt announced that it was abandoning the second phase of its $\$ 90$ billion Toshka new valley project which was aimed at aiding the country deal with its increasing population. The project was reported to have failed at meeting any set targets with higher cost incurred (Okereke, 2017). Furthermore, reports show that over $\$ 100$ million was lost by Ghana from 2009 to 2011 as a result of inadequate execution of projects (Alagidede et al., 2013). As a final point, Zuofa (2014) highlighted that IT projects embarked on by the Abuja Investment and Property Development Company (AIPDC) in Nigeria experienced failure and cost approximately $\mathrm{A}$ 3.8billion.

These projects indicate that there is a high rate of failure; however, what constitutes the term project failure largely depends on who defines it (lka, 2009; Mar, 2012; Carvalho, 2014) or who defines the scale for measuring success (Mir and Pinnington, 2014). An instance of this is shown in an analysis of five cancelled software projects in which the customer in one of the projects classed it as a failed project because the new system was never used by the customer, and however, the supplier classed it as successful because the project's baseline was met (Ahonen and Savolianen 2010). This implies that different stakeholders in a project will have different views of what is considered as failure or success.

Regardless of who defines project failure, a project can be classified as a total failure if it is abandoned before its completion stage (Heeks, 2006). An example of this is the Abia State road construction projects in Nigeria which commenced in 2010 and abandoned before completion in 2013 due to paucity of funds (Amade, et al., 2015). Evidently, the term project failure can have a varied or unanimous meaning. From previous literature, a unified agreement has not been reached on the constituents and definition of project failure. Majority of the orthodox definitions revolve around the projects constraints which (Atkinson, 1999) terms as the "Iron Triangle". Abednego and Ogunlana, (2006) suggest that these definitions restrict the performance solely to the managerial part of the project. Despite this, the increase in information and the awareness of project management professionals of the presence of different stakeholders in a project (Pantanakul, 2014), has caused a change in the definition of project success and failure towards post-delivery stages. Although, changes in the definition of project success and failure have been acknowledged, several authors ended their studies on the premise that cost, time and quality should be the indicators used to assess project success or failure (El Emam and Koru, 2008), therefore, it means that failure has occurred if one or all of the project constraints, time, cost and quality are not met.

\section{Causes of project failure globally}

In recent years, a lot of discussions have been raised on the topic of project failure by project management professionals globally, and a number of studies have focused on this topic. These studies show that there are several reasons projects fail globally (Long et al. 2004; Ahsan and Gunawan, 2010).

Due to the diversity of projects and industries involved in project delivery, each project is unique, hence, no two projects are completely similar. As a result of this, the factors that affect project delivery and eventually lead to failure are different across industry and location etc. (Ahsan and Gunawan, 2010). However, previous studies show that some causes of failure are similar across different projects. The similar causes are further discussed in the following sub-section.

\section{Project Resource}

According to literature, resources can be further classified into tangible and intangible resources (Das and Teng, 2000; Teigland and Lindvist, 2007; Damoah, 2015). Examples of these resources are: material, human, space and financial resources, etc. (Teigland and Lindvist, 2007; Damoah, 2015). The lack orinadequacy of resources have been found to cause projects to fail. One of such resources is the human resource. For example, reports on the 2010 world cup in South Africa showed that insufficient labour during the construction phases of the stadiums was one of the major causes of delays and cost overruns (Baloyi and Bekker, 2011). In addition, a study conducted on Malaysian construction projects showed that insufficient labour (skilled and unskilled) are major causes of failure (Sambasivan and Soon, 2007). According to Rahim et al. (2016), a report by Grant Thornton international recorded a $39 \%$ global shortfall of skilled workers with more than $60 \%$ in 
Malaysia. This inadequacy of skilled workers in the country created an increase in foreign workers (Salleh, et al., 2014) and, although this rise in foreign workers aids to reduce the shortages experienced, the problems that may arise due to multicultural workers and varying work principles are also a major concern (Muriithi and Crawford, 2003).

Another resource from literature which commonly results in project failure is the material resource. These materials are the tangible products required to execute some projects. Damoah (2015) suggests that projects which need physical deliverables cannot be executed without material resources. Material related factors are one of the major causes of delays. Likewise, studies into Nigerian projects have shown that inadequacy and delays in supply of materials needed for executing projects were causing project delays (Kog, 2017).

Furthermore, as finance is considered a resource during project execution, problems associated with finance is regarded as one of the major factors that lead to project failure. Studies show that many projects have failed globally as a result of poor management, inadequacy or lack of finances (Pourrastam and Ismail, 2011; Abbasi et al. 2014; Zuofa, 2014). Some construction projects experience delays caused by financial issues. These issues are also experienced in Nigeria where studies show that clients' financial difficulty is one of the major causes of delays and abandonment of projects (Zuofa, 2014).

\section{Project Planning}

Undeniably, planning is a crucial part of any project and in order to achieve success, a proper plan must be made. Poor project planning is a common cause of failure. Pinto (2013) suggests that in an event that clear outlines of deliverables in a project are not stated while planning, the project might fail. This simply means that projects which commence without a proper plan and knowledge of the constraints involved is at risk of failing. Studies show that poor planning is a root cause of many project failures in Iran (Pourrastam and Ismail, 2011). Similarly, this same problem was found in the Nigerian construction projects (Okwandu, 2010).

\section{Change in Project Scope}

According to previous literature, one of the primary factors that lead to project failure is the change of project scope (Taherdoost and Keshavarzsalehc 2016; Sudhakar, 2016). Many projects face changes in requirements before or during its execution. However these changes are not often accomplished at the expected date of completion. Ahonen and Savolianen (2010) suggest that evidence of this is predominant in IS projects.

Although changes in project scope are generally considered as a characteristic of projects, they usually have a huge effect on the project. Ayal (2005) stated that changes in project scope significantly affect project cost.

\section{Communication}

Various past studies have shown that efficient communication is a key element in a project as it aids in providing relevant information to all project participants, which is mandatory for delivery of successful project (Zulch, 2014; Ikechukwu, et al., 2017). Hence, poor communication while planning and executing projects is likely to cause failure.

According to Zulch (2014), communication is the process of collecting vital data, processing it and distributing the information to who and where it will be needed. Additionally, information can be defined as processed data which are presented in an understandable and meaningful format (Bowen and Edward, 1996). Evidently, effective communication is the bond which aids a project team to achieve its goals while miscommunication poses a threat to project success. Hussein, et al. (2018) identified the causes of poor communication in the construction industry as: linguistic barriers, cultural barriers, poor feedback and unclear communication channels amongst others. The first two causes listed are dominant in projects that involve multicultural collaboration. Feedback shows how project participants react to certain information and task, and it is essential to complete communication. Emphasis on the quality and timing of the feedback is therefore very essential, especially when it requires immediate attention (Gunhan, Senol, and Dogan, 2012). Lastly, communications channels which are not clear can pose a problem to the parties exchanging information, therefore an acceptable communication route for every project needs to be established (Zulch, 2014).

\section{Causes of Government Project Failure in Nigeria}

Various reasons have been attributed to the causes of government project failure in Nigeria. These identified causes include, poor financial capacity, inaccurate cost estimates, corruption, incompetence and lack of knowledge, poor 
planning and monitoring, political instability (Ogunmola, 2015; Nweze, 2016), amongst others. The following section discusses the identified causes.

\section{Poor financial capacity}

As is generally known, projects cannot be executed without the required funds. However, reports show that many Nigerian projects have experienced issues such as delays and abandonment as a result of financial problems (Akande, et.al. 2018a). In Nigeria today, the practice of returning unexhausted budgeted funds to the national coffer at the end of each financial year by government ministries and agencies have left projects with inadequate funds during this periods, and in turn, increasing the likelihood of project failure.

On a different note, the problem of poor financial capacity is not limited to the government. Contractors involved in government projects are also a major contributory factor to project failure as many contractors are not financially capable of executing these projects. As contained in the Nigerian procurement act, every contractor must have the required capital outlay to execute the project before a bid is submitted. Regardless of this principle, contracts are awarded to contractors who lack the capacity to execute the required project, hence, increasing the problem of project failure.

Budgetary detriments have been linked to a high rate of project failures in Nigeria. Ubani and Ononuju (2013) established that the slow or nondisbursement of funds from the government towards the implementations of projects due to corruption, toxic bureaucracy, zero allocations made to projects, has seen a high rate of project failures of roads, buildings, energy and other infrastructural spheres within Nigeria. Dim (2018) established that indeed a high number of road construction projects in Nigeria are failures.

\section{Inaccurate costing and corruption}

The ability to accurately estimate project cost is vital to achieve success (Botchkarev, 2015). Majority of government projects in Nigeria suffer from the problem of inaccurate cost estimations which is caused by several factors amongst which is corruption. Nweze (2015) states that ministries and Agencies responsible for delivering projects in Nigeria are handed the power of starting and monitoring their projects, thereby creating room for unchecked manipulation of project cost. Gyimah/Boadi (2002) state that systems that have weak monitoring and accountability create room for corrupt practices. Furthermore, contractors exploit the process and produce false reports that are in their favour. According to Damoah (2015) the issue of corruption has been cited in favour of those perpetuating it with reasons such as poverty being the primary cause.

The effects of these practices on Nigeria are numerous and range from the inadequacy of basic infrastructure such as access to clean water, to increasing unemployment and poverty rate (ljewereme, 2015). Although attempts have been made to stop these practices, the problem still lingers and contributes to the menace of project failure in the country.

\section{Incompetence and lack of knowledge}

In Nigeria today, despite the high population, most projects suffer from inadequate skilled professionals to execute the project (Kuroshi and Lawal, 2014; Okuntade, 2015). Nweze (2016) cited reasons such as migration of skilled professionals to other countries as part of the contributory factors to the issues of incompetence in Nigerian projects, thus, causing an increase in the adoption of foreign professionals at high cost.

Undeniably, a sound knowledge and application of project management significantly improve project success rates. However, government projects in Nigeria suffer from failure as a result of poor project management practices. For example, a study conducted by Olateju et al. (2011) on project management practice in the Nigerian public sector showed a lack of core knowledge of project management tools such as Gantt charts among project professionals.

\section{Poor planning, and estimation}

As a result of the inadequacy of knowledge of project professionals in Nigeria, most projects become afflicted with issues of planning and monitoring. According to literature, project planning, control and monitoring is extremely important in order to execute successful projects (Adebayo et al., 2018).

Lack of skilful planning, estimation and scheduling in the implementation of projects has been established to cause significant failure in projects across Nigeria. Poor contractor estimation, time horizons for their implementation and cost estimations have closely been established to cause failures in projects in Nigeria (Dosumu \& Aigbavboa, 2017). The planning shortcomings arise in poor development of objectives and clear-cut roadmaps to attaining 
them. Thus projects have been embarked upon haphazardly devoid of structured progressions which have altogether caused significant failures in most of the projects undertaken in Anambra State, Nigeria (Nzekwe, et al., 2015).

\section{Political instability}

No country has ever had any successful project under political instability. A case in point is Nigeria which witnessed several military regimes which were acquired through force of arms. Even a democratic system of government as it is now in Nigeria, witnesses several project failures because of instability in the running of government. Several government projects such as Aluminium Smelting Company at Ikot Abasi, Akwa Ibom State, Ajakuta Iron Company, etc., have failed due to unstable government in Nigeria.

\section{Poor Communication}

Poor communication between the various stakeholders in public projects within Nigeria has been affirmed to be a leading cause to project failure in Nigeria. Poor communication could be between the Federal government and State governments, government and the private stakeholders enjoined in the projects, the government and the local communities, and project implementation parties (Ogundelea \& Somefunb, 2008; Dim, 2018). The aspect of poor communication has also been linked to delays in the implementation of projects in Nigeria which in turn results in project abandonment and failure altogether.

\section{Poor Contracting and Contractor Practices}

Contractor-related causes of project failure have also been linked to the growing number of project failures in Nigeria. Poor contracting practices linked to poor contracts agreed upon with contractors, contractors' deliberate nonperformance on awarded contractors, and embezzlement of allocated budgets to contractors have seen sub-par delivery of projects, late deliveries and the all-dreaded abandonment and failure of public projects across all states within Nigeria (Uyo, 2019). The contracting challenges that contribute to failures have been linked to nepotism and tribalism in awarding of contracts in a rather biased manner which has led to high failures.

\section{Frequent Design Scope Changes and Errors}

On the other hand, persistent changes made to the established design, errors and defective designs push forward for implementation have been established to be closely impactful on the failure of projects in Nigeria (Dosumu \& Aigbavboa, 2017). Similarly, design changes and errors increase the costs of the projects, delay implementation and impede on the successful implementation of building projects in Nigeria (Onungwa, et al., 2017; Dosumu \& Aigbavboa, 2017). These 'design change' related impacts have led to project failures in several public projects across Nigeria. Anigbogu and Shwarka (2011)further said that up to $50 \%$ of all projects in Nigeria fail before commencement due to design issues.

\section{Socio-Cultural and Political Interferences}

Socio-cultural interferences through conflicts and incessant opposition to public projects have been established to confer impediments to project completion in Nigeria. Similarly, the lack of continuity in projects established which has seen succeeding governments fail to allocate funds for completion of projects started by their predecessors (Nweze, 2016). Such a lack of coherence in the political class towards development more so, the implementation of projects has seen projects fail across Nigeria. For instance, the Gas Revolution Industrial Park, Ogidigben in Delta State and the Gelegale Seaport in Edo State, have both failed to start despite the preparedness of the foreign and local governments towards the projects (Yusuf, 2018; Okoromadu, 2019). This is because of the conflicts and sabotage caused by them on the implementation of these two projects.

\section{Poor Leadership and Corruption}

Poor leadership and corruption in the design, contracting, estimation and implementation of projects have seen projects balloon in costs, rack up time overrun become too costly for governments across Nigeria which have led to abandonment and failure (Sonuga et al. 2002). Corrupt public servants who embezzle funds, engage in dubious contracts for self-gain have led to financial issues which have caused failures, stalling of projects, delays and abandonments across infrastructural projects.

\section{EFFECTS OF PROJECT FAILURE Loss of State Revenue}

Loss of state revenue has been established to be a leading effect of project failure within Nigeria. It is important to understand that less than $16 \%$ of projects in road construction alone in Nigeria end up successful despite the heavy investment from 
the government towards this sector (Dim, 2018). Loss of revenue throughout the designing, contracting, and implementation processes of these infrastructural projects is evident in Nigeria. Sahara Reporters (2019) puts the wasted revenues at 2 trillion Naira ( $\$ 5.517$ billion) between the years 2000 and 2019. These huge revenues cannot be recovered and thus, such wastages lead to huge losses in resources to the Nigerian community.

\section{Project Cost Overruns}

Project failure has also been found to cause project cost overruns to stakeholders enjoined in the agreed-upon contracts. Inherently, with the failure of a project, the government as a stakeholder will be required to compensate the local community displaced to give room for the project's implementations in addition to costs incurred in the concomitant delays (Nweze, 2016). Conversely, contractors will have to pay up for their credit facilitations in undertaking the projects. Therefore, with the failure of projects, stakeholders are tied to honour the agreements of their contractors with the greatest burden being economic/financial effects.

\section{Loss of Revenue by Citizens}

Project failure has a close impact on local citizens' life because it leads to a loss of revenues. This is because, project implementation opens up local citizens and communities to employment and commercial opportunities in labour supply, material supply and procurement gains as the contractors outsource locally. These investments in Nigeria confer a widespread impact on the local community and by closing a project, the revolving revenue streams tend to be cut. Moreover, with the closure of these projects, local communities lose out on the economic gains these projects would have had on their business activities which have been aggregated into revenue loss (Tell, 2008). Hence, there is a resultant loss in revenue for the local community as a result of project failure.

\section{Sub-standard Infrastructure}

It has been established that project failure and incomplete projects have resulted in the 'handing over' of substandard infrastructure to the local community. Project failure has been established to be fuelled due to financial and leadershiprelated challenges across Nigeria owing to corruption and financial issues (Eneh, 2011). These challenges have been established to compel project implementation teams to present sub-standard work to fit the meagre budget allocated or to embezzle the accorded revenues for personal benefits (Olufemi, 2013). Collectively, these aspects of leadership and financial management failures have seen the local Nigerian grapple with sub-standard infrastructural projects with the bulk of the resources allocated to them being embezzled.

\section{Low empowerment to Community}

It has been established that disempowerment of the local communities is a resultant effect to local communities in regions where these projects failed. Low empowerment has been established in loss of employment opportunities which develop capacity with the community within which the projects are undertaken. Alternatively, economic deprivation of the local community of the vital infrastructural development has been established to be a resultant effect of these project failures within these communities. Therefore, through the failure of these projects, the local Nigerian community intended to benefit from them gets to lose its intended empowerment enshrined in the aims of these projects which are inherently structured for altruistic reasons.

\section{CONSEQUENCES OF PROJECT FAILURE Slow Economic Growth}

Project failure has been linked to slow or derailed economic growth in the community within which the projects were to be implemented in Nigeria. A case in point is the $\$ 20 \mathrm{bn}$ Ogidigben Gas Industrial Park in Delta state which was positioned to be a game-changer in the oil refinery. Yusuf (2018) reports that the failure in kick-starting this project has seen the Ogidigben community still languish in economic underdevelopment despite the readiness of financial support from stakeholders. Therefore, project failure has been established to significantly hamper the exploitation of economic opportunities that could have arisen from the implementation and operation of the specific project across Nigeria. Thus, the overall economy of the country has suffered reduced growth levels owing to the failure of essential projects.

\section{Sector-Centric Underdevelopment}

It has been established that the failure of projects leads to low development rates in the associated sectors within Nigeria. For instance, the Ogidigben oil refinery project portrays a model of an expansive refinery in the Delta region in Nigeria which was positioned to open up 
opportunities to industry-players. However, the failure of the refinery to take off since 2015 has seen the regions slow down its progression to the refinery of crude oil extracted from the region (Yusuf, 2018). This has resultantly led to the low development of the oil sector which is the leading foreign exchange earner in the economy.

\section{Loss of Foreign Aid/Grants}

A grave consequence which has been noted with the rising number of failed projects in Nigeria is the loss of foreign or donor support in the local projects undertaken in the country. Naturally, development partners to Nigeria offer both technical and financial support to the implementation of infrastructural projects that are deemed vital economically (Adeyemo \& Amade, 2016). However, the rising leadership failure evident in embezzlements and misappropriation of funds by the local governments and its leaders, has led to donor support withdrawals.

\section{Tougher Donor Regulations}

Tougher donor regulations have also been established to be a detrimental consequence of project failure. The embezzlement and poor management of donated funds have been established to be reasons enough for increased requirements for local Nigeria governments to meet in order to be awarded these resources (Sunjka \& Jacob, 2013). These regulations seek to seal the loopholes in accounting practices, project planning, design and implementation in order to ensure that the intended goal is met in Nigeria.

\section{Loss of Elections to Incumbent}

Loss of an election to an incumbent political leader due to the failure of a particular project has been established as tangible grounds for a political leader to lose elective seat. With the growing appetite for infrastructural development projects, the failure to successfully complete these projects has been seen to cost some incumbents their seats. Therefore, from a political perspective, project implementation is closely tied to the approval rating of leaders in Nigeria.

\section{Lack of Confidence in State from Financial Institutions}

A grave consequence established to emanate from project failure is the loss of confidence in financial institutions on the governments for resources credited to them. The embezzlement of funds, failure to confer intended goals from projects by the implementing governments, lack of accountability and poor efficiency in the process of implementing these projects have resulted in low confidence accorded to government. As a result, failure to secure credit facilities from these institutions has also been established as a detrimental consequence to the economic development of these communities in Nigeria.

\section{CONCLUSION}

Nigerian government needs a national policy, and if necessary, legislative approach, to address the problem of project failure in the country. The impacts of project failure on individual citizens and the national economy are extremely negative and require mitigation.

\section{REFERENCES}

Abbasi, N., Wajid, I., Iqbal, Z., and Zafar, F., 2014. Project failure case studies and suggestion. International Journal of Computer Applications , 88 (6).

Adebayo, O., Eniowo, O., and Ogunjobi, V., 2018. Assessment of project monitoring and control techniques in Ondo State Agency for Road Maintenance and Construction (OSARMCO). International Journal of Engineering and Management Research , 8 (5), 177.

Adeyemo, A., and Amade, B., 2016. Corruption and construction projects in Nigeria: manifestations and solutions. PM World Journal , 5 (10).

Ahonen, J., and Savolianen, P., 2010. Software engineering projects may fail before they are started: Post-mortem analysis of five cancelled projects. Journal of Systems and Software , 83 (11), 2175-2187.

Ahsan, K., and Gunawan, I., 2010. Analysis of cost and schedule performance of international developmental projects. International Journal of Project Management , 28 (1), 68-78.

Akande, O. e., 2018b. Evaluation of Failures in Public Project Management Practices in Minna, Nigeria. Journal of Architecture and Construction , 1 (3), 15-24.

Akande, O. e., 2018a. Exploring Factors Influencing of Project Management 
Success in Public Building Projects in Nigeria. YBL Journal of Built Environment , 6, 47-62.

Aladwani, A., 2016. Corruption as a source of eGovernment projects failure in developing countries: A theoretical exposition. International Journal of Information Management , 36, 105-112.

Alagidede, P., Baah-Boateng, W., and NketiahAmponsah, E., 2013. The Ghanaian Economy: An Overview. Ghanaian Journal of Economics , 1, 4-34.

Alami, A., 2016. The UK e-Borders Project Failure. PM World Journal , 5 (3).

Allen, M., Alleyne, D., Farmer, C., McRae, A., and Turner, C., 2014. A Framework for Project Success. Journal of Information Technology and Economic Development $5(2), 1$.

Amachree, S., 1988. Investment Appraisal in Developing Countries. England: Avebury Gower Publishing Company Ltd.

Amade, B. e., 2015. Factors for containing failure and abandonment of public sector construction projects in Nigeria. Journal of Building Performance , 6, 2180-2106.

Anderson, D., Sweeney, D., Williams, T., Camm, J., and Cochran, J., 2015. An introduction to management science: quantitative approaches to decision making (14th ed.). San Francisco, CA: Cengage learning.

Anigbogu, N., and Shwarka, M., 2011. Evaluation of the impact of the public procurement reform program on combating corrupt practices in public building projects delivery in Nigeria. Environtech Journal , 1 (2), 43-51.

Atkinson, R., 1999. Project management: Cost, time, and quality, two best guesses and a Phenomenon, it's time to accept other success criteria. International Journal of project Management , 17 (6), 337-342.

Ayal, M., 2005. Effect of Scope Changes on Project Duration Extensions. Tel Aviv: Tel Aviv University.
Aziz, R., 2013. Factors causing cost variation for constructing wastewater projects in Egypt. Alexandria Engineering Journal , 52 (1), 51-66.

Baloyi, L., and Bekker, M., 2011. Causes of construction cost and time overruns: The 2010 FIFA World Cup stadia in South Africa. Acta Structilia , 18 (1), 51-67.

Bell, E., Bryman, A., and Harley, B., 2018. Business research methods (4th ed.). Oxford: Oxford university press.

Belout, A., and Gauvrean, C., 2004. Factors Influencing the Project Success: The impact of human resource management. International Journal of project Management , 22, 1-11.

Botchkarev, A., 2015. Accuracy of estimating project costs and benefits: An overview of research in information systems. Journal of Emerging Trends in Computing and Information Sciences , 6 (6), 290-298.

Bowen, P., and Edwards, P., 1996. Interpersonal communication in cost planning during the building design phase. Construction Management and Economics , 14 (5), 395-404.

Bryman, A., 2012. Social Research Methods. Oxford: Oxford University Press.

Carvalho, M., 2014. An investigation of the role of communication in IT projects. International Journal of Operations and Production Management , 34 (1), 36-64.

Cheng, Y., 2014. An exploration into costinfluencing factors on construction projects. International Journal of Project Management , 32 (5), 850-860.

Cohen, L., Manion, L., and Morrison, K., 2013. Research Methods in Education (7th ed.). Oxford: Routledge.

Cousillas, S., Rodríguez, V., Concepción, R., and Rodríguez, F., 2010. Identification and analysis of causes for project failure and factors for project success in the Asturian case. In XIV International Congress On Project Engineering. Madrid. 
Damoah, I., 2015. An investigation into the causes and effects of project failure in government projects in developing countries: Ghana as a case study (Doctoral dissertation, Liverpool John Moores University).

Damoah, I. S., and Akwei, C., 2017. Government project failure in Ghana: a multidimensional approach. International Journal of Managing Projects in Business , 10 (1), 32-59.

Damoah, I., and Kumi, D., 2018. Causes of government construction projects failure in an emerging economy: evidence from Ghana. International Journal of Managing Projects in Business , 11 (3), 558-582.

Das, T., and Teng, B., 2000. A resource-based theory of strategic alliances. Journal of management , 26 (1), 31-61.

Dim, N., 2018, November 7. Project Failure in the Nigerian Construction Industry: Cases of Highway Construction Projects by the Nigerian Ministry of Works.

Dosumu, O., and Aigbavboa, C., 2017. Impact of design errors on variation cost of selected building project in Nigeria. Procedia engineering , 196, 847-856.

Dwivedi, Y., Wastell, D., Laumer, S., Henriksen, H., Myers, M., Bunker, D., et al., 2015. Research on Information Systems Failures and Successes: Status Update and Future Directions. Information Systems Frontiers , 17 (1), 143-157.

El Emam, K., and Koru, A., 2008. A replicated survey of IT software project failures. IEEE software , 25 (5), 84-90.

Eneh, O., 2011. Failed development vision, political leadership and Nigeria's underdevelopment: A critique. Asian Journal of Rural Development , 1 (1), 6369.

Eriksson, P., and Kovalainen, A., 2015. Qualitative methods in business research: A practical guide to social research. Sage.
Fabian, C., and Amir, A., 2011. The ChadCameroon Pipeline Project--Assessing the World Bank's Failed Experiment to Direct Oil Revenues towards the Poor. The Law and Development Review , 4 (1), 32-65.

Florentine, S., 2017. IT projects success rates finally improving. Retrieved July 27 , 2019, from https://www.cio.com/article/3174516/itproject-success-rates-finallyimproving.html

Gunhan, S., Senol, G., and Dogan, S. Z., 2012. Non-verbal cues: improving communication in construction projects.

Gyimah-Boadi, E., 2002. Confronting corruption in Ghana and Africa, briefing paper: Ghana Centre for Democratic Development (CDD-Ghana). 4 (2), 1-6.

Hanachor, M., 2013. Community Development Projects Abandonment in Nigeria: Causes and Effects. Journal of Education and Practice , 3 (6), 33-36.

Heeks, R., 2006. Health information systems: Failure, success and improvisation. International Journal of Informatics , 75 (2), 125-137.

Hoang, H., and Rothaermel, F., 2005. The effect of general and partner-specific alliance experience on joint R\&D project performance. Academy of Management Journal, , 48 (2), 332-345.

Hussien, M. e., 2018. Causes and Impacts of Poor Communication in the Construction Industry.

ljewereme, O., 2015. Anatomy of Corruption in the Nigerian Public Sector. SAGE Open , $5,1-6$.

Ikechukwu, A., Fidelis, I., and Celestine, O., 2017. Effective communication as a panacea for conflict avoidance in public building construction project delivery. International Journal of Advanced Research in Engineering and Management , 3 (3), 38-53. 
Janssen, M., and Klievink, B., 2010. Ict-project failure in public administration: The need to include risk management in enterprise architectures. Proceedings of the 11th Annual International Digital Government Research Conference on Public Administration Online: Challenges and Opportunities , 147-152.

Kog, Y., 2017. Major delay factors for construction projects in Nigeria. International Journal of Architecture, Engineering and Construction , 6 (2), 4654.

Kothari, C., 2008. Research Methodology: Methods and Techniques. New Delhi: New Age International.

Kuroshi, P., and Lawal, M., 2014. Study of Internal Factors Affecting Labour Productivity in Medium Sized Construction Firms in Nigeria. International Journal of Education and Research , 2 (12), 83-92.

Liu, J., Chen, H., Chen, C., and Sheu, T., 2011. Relationships among interpersonal conflict, requirements uncertainty, and software project performance. International Journal of Project Management , 29 (5), 547-556.

Long, N., Ogunlana, S., Quang, T., and Lam, T., 2004. Large construction projects in developing countries: a case study from Vietnam. International Journal of Project Management , 22 (7), 553-561.

Lune, H., and Berg, B., 2016. Qualitative research methods for the social sciences. Pearson Higher Education.

Mar, A., 2012. 5 Definitions of project failure. Retrieved July 16, 2019, from http://management.simplicable.com/man agement/new/5-definitions-ofprojectfailure

May, T., 2011. Social Research: Issues, Methods and Research. London: McGraw-Hill International.

Mir, F., and Pinnington, A., 2014. Exploring the value of project management: Linking Project Management Performance and
Project Success. International Journal of Project Management , 32 (2), 202-217.

Mirza, M., Pourzolfaghar, Z., and Shahnazari, M., 2013. Significance of scope in project success. Procedia Technology , 9, 722729.

Muriithi, N., and Crawford, L., 2003. Approaches to project management in Africa: implications for international development projects. International journal of project management , 21 (5), 309-319.

Myers, M., 2013. Qualitative research in business and management (2nd ed.). London: Sage Publications.

Nelson, R., 2007. IT project management: Infamous failures, classic mistakes, and best practices. MIS Quarterly executive , $6(2)$.

Note, M., 2015. Project management for information professionals. Chandos Publishing.

Nweze, N., 2016. Failure of Public Infrastructure Projects in Nigeria: Causes, Effects and Solutions. Textile International Journal of Management , 2 (2), 1-20.

Nzekwe, J., Oladejo, E., and Emoh, F., 2015. Project failure as a reoccurring issue in developing countries: focus on Anambra State, South East, Nigeria. International Journal of Energy and Environmental Research , 3 (3), 1-20.

Ogundelea, O., and Somefunb, O., 2008. SDI: PROSPECTS AND CHALLENGES FOR FEDERAL STATE DEVELOPING COUNTRIES (Case of Nigeria). . The International Archives of the Photogrammetry, Remote Sensing and Spatial Information Sciences, XXXVII, 31-37.

Ogunmola, E., 2015. Why do projects fail? The Nigerian Government insensitivity to project failure. PM World Journal , 4 (4).

Ogwueleka, A., 2011. The critical success factors influencing project performance in Nigeria. International Journal of 
Management Science and Engineering Management , 6 (5), 343-349.

Okereke, O., 2017. Causes of failure and abandonment of projects and project deliverables in Africa. PM World Journal , 6 (1), 1-16.

Okoromadu, F., 2019. Nigeria: Conflict Responsible for Poor Investment in Niger Delta Region - Report. Retrieved August 20, 2019, from https://allafrica.com/stories/20190819012 4.html

Okuntade, T., 2015. Shortage of skills workers in the Nigerian construction Industry: A paradigm of a Failed government Policy.

Okwandu, G., 2010. Construction Project Management In Nigeria: Challenges and the Way Forward.

Olateju, O., Abdul-Azeez, I., and Alamutu, S., 2011. Project Management Practice in Nigerian Public Sector-An Empirical Study. Australian Journal of Business and Management Research , 1 (8), 1.

Oloruntobi Dada, M., 2013. Expected success factors for public sector projects in Nigeria: a stakeholder analysis. Organization, technology and management in construction: an international journal , 5 (2), 842-859.

Olufemi, A., 2013. Construction project financing for sustainable development of Nigerian cities. FIG Week 2013-Environmental for Sustainability , 3 .

Onungwa, I., Uduma-Olugu, N., and IGWE, J., 2017. Building information modelling as a construction management tool in Nigeria. WIT Transactions on The Built Environment , 169, 25-33.

Panayides, P., Parola, F., and Lam, J., 2015. The effect of institutional factors on publicprivate partnership success in ports. Transportation Research Part A: Policy and Practice , 71, 110-127.

Patanakul, P., 2014. Managing large-scale IS/IT projects in the public sector: Problems and causes leading to poor performance.
Journal of High Technology Management Research , 25 (1), 21-35.

Pellissier, R., 2008. Business research made easy. Cape Town, SA: Juta and Company Ltd.

PMI., 2013. A Guide to the Project Management Body of Knowledge (PMBOK Guide) (5th ed.). Project Management Institute.

Pourrostam, T., and Ismail, A., 2011. Significant Factors Causing and effects of Delay in Iranian Construction Projects. Australian Journal of Basic and Applied Sciences , 5 (7), 45-450.

Rahim, F., Yusoff, N., Chen, W., Zainon, N., Yusoff, S., and Deraman, R., 2016. The challenge of labour shortage for sustainable construction. Planning Malaysia Journal , 14 (5).

Rajablu, M. e., 2015. Managing for Stakeholders: The Role of Stakeholder-Based Management in Project Success. Asian Science, 11.

Sahara Reporters., 2019. N2 Trillion Wasted On Constituency Projects Since 2000 Nigeria's Anti-Corruption Agency. Retrieved August 20, 2019, from http://saharareporters.com/2019/07/22/n 2-trillion-wasted-constituency-projects2000-\%E2\%80\%93-nigerias-anticorruption-agency

Salleh, N., Mamter, S., Lop, N., Kamar, I., and Hamdan, N., 2014, August 27. The escalating of numbers of foreign workers in construction site. BSFMEC 2014 Building Surveying, Facilities Management and Engineering Conference .

Sambasivan, M., and Soon, Y., 2007. Causes and effects of delays in Malaysian construction industry. International Journal of project management , 25 (5), 517-526.

Saunders, M., Lewis, P., and Thornhill, A., 2012. Research methods for business students (6 ed.). Harlow: Pearson. 
Saxena, A., 2016. Avoiding project failure by using project management methodologies (Doctoral dissertation, Dublin Business School).

Shahhossein, V., Afshar, M., and Amiri, O., 2018. The root causes of construction project failure. Scientia Iranica , 25 (1), 93-108.

Soliman, E., 2010. Delay causes in Kuwait construction projects. AICSGE7, Proceedings of Seventh Alexandria International Conference on Structural and Geotechnical Engineering , 57-67.

Solon, O., 2015. Failed Government IT projects waste $£ 100$ milion of taxpayers' money in just one year. Retrieved July 20, 27, from https://www.mirror.co.uk/news/technolog y-science/technology/failed-governmentprojects-waste-100-5176871

Sonuga, F., Aliboh, O., and Oloke, D., 2002. Particular barriers andissues associated with projects in a developing and emerging economy: Case study of some abandoned water and irrigation projectsin Nigeria. International Journal of Project Management , 20 (8), 611-616.

Sudhakar, G., 2016. Critical Failure Factors (CFFs) of IT Projects. International Journal of Management Research , 4 (2).

Sunjka, B., and Jacob, U., 2013. Significant causes and effects of project delays in the Niger delta region, Nigeria. Southern African Institute of Industrial Engineering

Taherdoost, H., and Keshavarzsalehc, A., 2016. Critical Factors that Lead to Projects' Success/Failure in Global Marketplace. Procedia Technology , 22, 1066-1075.

Tell., 2008. Tell. Ikeja, Nigeria: Tell Communications Ltd.
Todorović, M. L., Petrović, D., Mihić, M., Obradović, V., and Bushuyev, S., 2015. Project success analysis framework: $A$ knowledge-based approach in project management. International Journal of Project Management , 33 (4), 772-783.

Turner, J. R., 1993. The Handbook of projectBased Management: Improving the process for achieving strategic objective. London: McGraw-Hill.

Ubani, E., and Ononuju, C., 2013. A study of failure and abandonment of public sector-driven civil engineering projects in Nigeria: an empirical review. American journal of scientific and industrial research , 4 (1), 75-82.

Ucbasaran, D., Westhead, P., and Wright, M., 2009. The extent and nature of opportunity identification by experienced entrepreneurs. Journal of Business Venturing , 24 (2), 99-115.

Uyo, B., 2019. Probe Contractors over failed road. Retrieved August 15, 2019, from https://thenationonlineng.net/probecontractors-over-failed-road-projects/

Wilson, J., 2014. Essentials of business research: A guide to doing your research project (2nd ed.). London: Sage Publications.

Yusuf, A., 2018. \$20bn Ogidigben Gas Park contracts hit the rock. Retrieved August 20, 2019, from https://www.newtelegraphng.com/2018/0 6/20bn-ogidigben-gas-park-contracts-hitthe-rock/ [Accessed 20 August 2019].

Zuofa, T., 2014. Project failure: The way forward and panacea for development. International journal of business and management,9(11) 